\title{
PSYCHOLOGY
}

\section{THE USE OF CORRECTIONAL GAMES IN THE WORK OF A SCHOOL PSYCHOLOGIST}

\author{
G. Hasanova ${ }^{1}$ \\ DOI: http://doi.org/10.15350/L_2/2/4
}

\begin{abstract}
The article is devoted to the role that is assigned in the psychocorrectional work of games and psycho-technical exercises. They are aimed at harmonizing the personality of the junior schoolchildren, elaborating the speech acquisition skills, the ability to establish contacts with adults and children, developing imagination, creativity, removing anxiety, aggressiveness, and eliminating low selfesteem. The relevance of this research borders on the increased need to optimize the learning process, for which it seems important to use the gaming methods in the practice of the psychologist which are necessary for a more effective organization of the correctional process. Psycho-technical games - exercises can be considered as an important element in the work of the school psychologist, as a starting point for the organization of psycho-preventive work in primary school. Exactly the complex measures connected with the conduct of psychodiagnostic, corrective and preventive work is contributing the creation of a favorable psychological climate in school collective.
\end{abstract}

Keywords: adaptation, game, correction, fear, anxiety.

The arrival of a child in school is a crucial and important stage in his socialization and development, connected with the difficulties of adaptation in a new collective. As noted in the work of Azerbaijani psychologists M. Veliyev and A. Mustafayev: "When a child comes to school, he must build his behavior based on the internal discipline of the school and take a slightly different form of behavior than his predecessors and teachers" [9, p. 125]. The problem that attracted our attention is the object of close attention of Russian scientists, such as Kulyagina I.Yu., Kolyutsky V.N. [5], Mukhina V.S. [6], Obukhova L.F. [7], Khukhlayeva 0. [4], as well as Azerbaijani psychologists [1,2,3,8]. This work was carried out as part of the preparation and implementation of a corrective program aimed at relieving tension, aggression, anxiety in a particular age group. Within the framework of this article, we have set tasks, from the solution of which depends the success of the work of a psychologist with junior schoolchildren: identification of psychological difficulties encountered by children of primary school age

${ }^{1}$ Gulnara Hasanova Ph.D. in Psychology, Associate Professor Baku Slavic University, Azerbaijan. 
(nervous conditions, fears, anxiety, isolation, alienation, etc.); development and approbation of the program on provision of psychological assistance to the identified control group. As probationers there were involved elementary school learners in the amount of 62 people (the number of students does not exceed 10 - 11 in one correction group). In order to identify children with learning difficulties it was conducted a survey of teachers and analysis of student progress. It were conducted diagnostic tests with selected students for the study of the following features: motivation (methods of M. R. Ginzburg "The story about the school", "Talk about school"), the identification of self-assessment (modification of the method Dembo - Rubinstein), the arbitrariness of mental functions (memory, attention, thinking), the speech acquisition, the development of imagination, communication skills (ability to establish contacts with adults and children), diagnostic and correctional work with anxious children.

With the results of primary diagnostics we drew up a program of psychological services, including specially organized classes, where were used a psychoeducational games, exercises, training form of work. In the Junior school age the most significant are such structural units of self-consciousness, as the awareness of the name, the claim to recognition and awareness of rights and responsibilities from this perspective, we believe that the prevention of these units of consciousness, should determine the content and logic of psycho-prophylactic work in the elementary school. We have used: games, exercises aimed at harmonizing the understanding of the name: to harmonize the claims for recognition aimed at the realization of children's rights and responsibilities. Integrated application of exercises, games - was a necessary condition in our work to alleviate anxiety in children. The classes were held in groups of 10 persons two times a week, lasting about 45 minutes. Each lesson consisted of several parts: introduction (the purpose is to create a confidential environment and to take off the emotional discomfort), the base (preventive work with defined structural units of consciousness); the final (a relaxation which allow to create the unity of the child with the collective, mutual supporting of group members).

Classes begin with gymnastics, which included exercises to develop attention and memory. Afterward were «micro lessons». It was conducted the two lessons with 20 minutes in each. It was a short break between them. The aim of these studies was removing the increased anxiety by means of desensitization caused by the educational situation. It was a short break after the micro lesson, and then began the gaming part of the lesson. The second part has started with the games, allowing children to put freely into expression, to remove the static pressure. Here it was included the games, jokes, finger plays, pantomime. Then followed the game - dramatization, relieving emotional tension and acting out of fear. Considerable attention was given to games with rules. The games with rules was mastered for a very long time, you can even call it studying and mastering each game, and the kids did it on their own initiative and with pleasure. It should be noted that the classroom part of the time allocated for the process of drawing, both free, and initially given topic that is known to be an important element in the work of overcoming anxiety, emotional instability. Then we moved on to stories about what a good, happy, bad or sad happened with the band during the 
breakup, telling what interesting things they learned during this time. Afterward it was carried out an assessment and self-assessment of success of the child at different stages of the lesson. Usually the lesson was concluded with the method of coloring. On a large sheet that was ruled for each child for all lessons, we noted how is the child's mood now with different shades of colored pencils. The next stage of the diagnostic study suggested the psychological correction of disorders of communication in primary school children in a game group and the results of the diagnostics revealed the following sources of maladjustment: the internal conflicts of the child, the family stereotypes of behaviors, the child's temperament peculiarities.

In some cases, the primary psychological examination of children seemed insufficient to identify the corrective group. There was a need to work with parents to identify difficulties in communicating with their children. After the full course of psycho-correction work with children, we carried out a repeated examination of children in the control group, as a result we have achieved significant changes in behaviour and emotional state of the children. Analysis of the results of the study confirmed the importance and necessity of the use of psychotechnical games - exercises in elementary school.

\section{References:}

[1] Amrahly L.Sh. Detskaja psihologija. Baku: izdatel'stvo AGPU, 2010, 358 s.

[2] Gamzaev M. A. Osnovy vozrastnoj i pedagogicheskoj psihologii. Baku, «Adil'oglu», 2003, $282 \mathrm{~s}$.

[3] Guliev E.M. Osobennosti razvitija poznavatel'noj dejatel'nosti u mladshih shkol'nikov. Baku: izdatel'stvo AGPU, 1995, $80 \mathrm{~s}$.

[4] Huhlaeva O.V. Psihotehnicheskie igry v nachal'noj shkole. Metodicheskoe posobie. M.: MOSU, 1996, $32 \mathrm{~s}$.

[5] Kulagina I.Ju., Koljuckij V.N. Vozrastnaja psihologija: Razvitie cheloveka ot rozhdenija do pozdnej zrelosti: Uchebnoe posobie dlja vuzov. M.: Jurajt, 2011, 464 s.

[6] Muhina V.S. Vozrastnaja psihologija: fenomenologija razvitija, detstvo, otrochestvo: Uchebnik. M.: Akademija, 2010, 452 s.

[7] Obuhova L.F. Vozrastnaja psihologija. M.: Rossija, 2011, 414 s.

[8] Seidov S.I., Gamzaev M.A. Psihologija. Baku: Nurlan, 2007, 700 s.

[9] Veliev M. Mustafaev A. Razvitie i vozrastnaja psihologija. Baku, «Jel'm», 2015, 297 s. 